\title{
Hijrah, Cultural Transformation for Social Empowerment: A Qur'anic Perspective
}

\author{
N A Febriani ${ }^{1}$ \\ Perguruan Tinggi Ilmu Qur'an (PTIQ), Lebak Bulus, Jakarta ${ }^{1}$ \\ \{royyana12@yahoo.com $\left.{ }^{1}\right\}$
}

\begin{abstract}
The hijrah practiced by Prophet Mohammadattributesphysical and spiritual dimensions. While physical hijrah means amigration from a discomfort place to a comfortable one, spiritual hijrah refers to culturaltransformation into a more civilized culture. Due tothe Prophet's hijrah, Muslims and non-Muslims lived in harmony. In Medina, different clans and tribes, Muslims and nonMuslims, agreed to practice tolerance to different faiths, to improve prosperity, and to guarantee safety under Constitution of Medina. This concept bears a high degree of relevance with the situation in Indonesia which is home to a multitude of religions, tribes, and cultures. This is because hijrah is mainly about social integration and social empowerment for the sake of advancement in religion and every element of a nation.
\end{abstract}

Keywords:Hijrah, Cultural Transformation, Social Empowerment

\section{Introduction}

The hijrah phenomenon among Indonesian youths was initially perceived as a changing behavior of dressing from partially to properly covering the awrah (an unexposable body). Recently, however, the meaning of hijrah is extended into a religion based social movement in many areas, including the entrepreneurial sector. It could be seen Indonesian millenials have a lot of enthusiasm about engaging with events such as "Hijrah Fest" as reported in islampost.com (2018) and hijrahfest.com (2019).

Does a question arise as to what forms of the cultural transformation are instituted by the Prophet upon the hijrah described in the Quran?

Etymologically, hijrah is derived from an Arabic verb hajara, which means to emigrate. A derived word of al-hijru or al-hijran means to abandon something, either physically, verbally, or silently. Hijrah refers to migration from one region to another as practiced by Muhajirun (the Emigrants), alongside the Prophet, from Mecca to Medina.

For some Muslim scholars, such as Ibn 'Arabi, Ibn Hajar, and Ibn Taymiyyah, hijrah etymologically means displacement from a state of war (dar al-kufr wa al-harbi) to a state of peace (dar al-Islam)[1]. However, it should be noted that, as Ibn Taymiyyah stated, dar al$k u f r$ does not refer to the territorial areas of a country that is inhibited by disbelievers $(k \bar{a} f i r)$ but to the characteristics of the inhibitors [2]. An 'Islamic' state is a state under Muslim leaders who rule the Islamic law, even if the state is majorly inhabited by non-Muslims [3].

Based on ibn Taymiyyah and al-Qathani's opinion above, Indonesia can be justified as dar al-muslim where people can live together in peace because the country is safe and peaceful, 
led by a Muslim leader under Islamic law, albeit only part of them have opposed to it. Since Indonesian have united in diversity, consist of diverse religions and tribes in harmony, this country could be a safe and peaceful country (dar al-Islam or state of peace).

In Qur'an, the term ha-ja-ra carries a variety of meanings, including 1. distasteful word/curse (al-Mu'minūn: 67), 2. migration from one state to another state to seek refuge (al'Ankabūt: 26), 3. abandoning a wife in her bed (al-Nisā': 34), and 4. secluding oneself without causing any conflict (al-Muzammil: 10 and Maryam: 46). Jazuli summed up the definition of hijrah as to abandon, in the sense of either conduct or verbal [1].

The history of Islam demonstrates that hijrah undertaken by Prophet and his Companions was intended to bring a change into the state of affiars when their lives were in danger. Their $d a$ 'wah had yet to get optimal outcomes, and the economy was in a dire condition due to Muslims' isolation from the community.

Their hijrah is not restricted to solely physical hijrah as in the Prophet's emigration with his Companions from Mecca to Medina or in their migration from a place of insecurity to a place of safety for the purpose of life preservation. In many hadith (the Prophet's sayings), hijrah is understood in the sense of a change from the prohibited (haram) to the commended (halal). This is what so-called spiritual hijrah [1], which brought about positive impacts on the transformation from the jahiliyyah culture into a more civilized Arab culture.

Hijrah per se is inextricably linked to betterment in akhlaq (morals). It illustrates that one's formal Muslim status needs to be accompanied with the application of core Islamic teachings in a substantive way.Upon the physical hijrah from Mecca to Medina, the Prophet taught Muhajirun and Ansar (the Helpers) to carry out transformation in akhlaq, as narrated by al-Bukhari and Muslim said,

"I have been sent for the perfection of character."

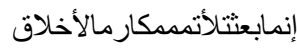

Another hadith said that Prophet elaborated on the characteristics of those who practice hijrah. He said,

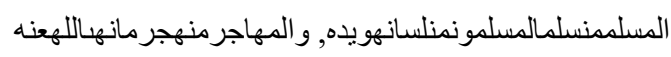

"A Muslim is someone who spares people the harm of his tongue and hand, and a migrator is someone who migrates from what God has forbidden." (Shahih Bukhari: I, no. 53).

Hijrah also means a believer's effort to keep away from all forms of wrongdoing and sin. The Prophet said,

$$
\text { المؤمنمنأمنهالناسعلأمو الهمو أنفسهر, و المهاجر منهجر الخطاياو الذنوب }
$$

"A Muslim is someone who allows safety to the belongings and lives of others, and a migrator is someone who keeps himself from all wrongdoings and sins." (Sunan Ibn Majah: 2, no. 1298).

The two hadith above generally highlights that hijrah is an individual Muslim's efforts to be a more submissive, visionary, and progressive person.

Throughout the history of the Prophet's and the Companions' hijrah, cultural transformation is undertaken toward a more civilized one. Da'wah (proselytizing) was more acceptable among people of Medina as the form of their transformational behavior. This paper is intended to point out some Islam endeavors for safety, peace, welfare, and happiness among people. 
The Prophet's spiritual hijrah had set an example of how increasingly progressive cultural transformation should be in the modern Indonesian context. The concept of spiritual hijrah will continuously evolve with human's dynamic thoughts.

\section{Method}

This research uses "Maudu'i interpretation method" (thematic method) because it could be used to comprehensively explore the concept of hijrah in the Qur'an. According to al-Farmawi, interpreting the Qur'an with thematic methods uses the following procedure:

a. Determining the themes in al-Qur'an which will be studied thematically.

b. Collecting verses based on relevant topics.

c. Arranging the verses chronologically by prioritizing the makiyah verses from madaniyah with knowledge about the background of verses.

d. Knowing the correlation (munāsabah) of these verses.

e. Arrange Arranging a discussion of the themes in a systematic outline

f. Completing the discussion with related traditions. [4]

\section{Result and Discussion}

The Cultural Transformation for Social Empowerment during Prophet Period: A Quranic Perspective

This section will figure out the Prophet's cultural transformation of the Muslim ummah and Medina people, both Muslim and non-Muslims. This transformation had impact on the patterns of interaction not only between family members and society but also on the society's economic empowerment [5].

Interestingly, many Madaniyyah sūrah/chapters (the sūrah/chapters of the Quran revealed after the Prophet's hijrah to Medina) consist of ayah (verse) on the transformation of Arab's jahiliyyah culture (culture in Age of Ignorance) into universal teachings on perseverance of unity and comradeship in a plural society. Madaniyyah chapters have described the cultural transformation of Arabs during Prophet's and his Companions' emigration to Medina.

By using al-Tafsir al-Maudu'i method, this study is to describe ways in which cultural transformation was carried out by the Prophet as described in sürah Madaniyyah: 1. transformation from qabilah (tribal) social system into ummah social system (brotherhood on a global and just basis); 2. transformation from paternalism into professionalism; 3 . transformation from patriarchy into gender equity; 4. transformation from confrontational into negotiation strategies; 5. transformation from "superman" (authoritarian) into "superteam" culture; 6. transformation from slavery to manumission; 7. transformation from monopoly into ummah-based economic empowerment; and 8. transformation from intellectual arrogance into intellectual humility. These cultural transformations are partly shown in Table 1 below:

Table 1. Cultural Transformation in Madaniya Sūra

\begin{tabular}{llll}
\hline No & Surah and Ayah & Keyword and Explanation & $\begin{array}{l}\text { Cultural } \\
\text { Transformation }\end{array}$ \\
\hline $\mathbf{1}$ & $\begin{array}{l}\text { Āli ‘Imrān/The Family } \\
\text { of Imrān [3]: } 104\end{array}$ & Ummah & $\begin{array}{l}\text { transformation from qabilah (tribal) } \\
\text { social system into ummah social }\end{array}$ \\
\hline
\end{tabular}




\section{Al-Baqarah/The \\ Heifer [2]: 143}

Al-An'ām/The Cattle
[6]: 135

al-Taubah/The

[9]: 105

Al-Ra'd/The Thunder [13]: 11

al-Taubah/The

Repentance/Immunity

[9]: 122

3 al-Taubah/The

Repentance/Immunity

[9]: 71

Al-Nisā'/The Women [4]: 59

\section{4}

5

Āli 'Imrān/The Family of Imrān [3]: 159 al-An'ām/The Cattle: 87

al-Hujurāt/the Inner Apartements [49]: 10

Q.S al-Isrā'/The Night Journey or The

Children of Israel

[17]: 70

al-An'ām/The Cattle: 38

al-'A'rāf/The Heights: 65

6

Al-Baqarah/The Heifer [2]: 177

7

al-Nūr/The Light [24]:
Repentance/Immunity

Ummatan washatan

(moderate society)

obligation to work

professionally with the best possible efforts

urgency of professionalism at work

professionalism in relation to responsibilities that comes with an expertise

professionalism in association with proportionality

cooperation between man and women

uli al-amr is persons who have authority to manage Muslim ummah, man or women

sharing opinions and negotiation

Ukhuwah

Dzuriyyah/brotherhood based

on lineage

Ukhuwwah

Islamiyyah/brotherhood

between Muslims

Ukhuwah

Insaniyyah/brotherhood

between human beings

Ukhuwah

Makhluqiyyah/relationship with other creatures

Ukhuwah

Wathaniyyah/brotherhood between citizens of a state the good deed of liberating a slave one 36 obligation rightly paid to the system (brotherhood on a global and just basis)

transformation from paternalism into professionalism;

transformation from patriarchy into gender equity

transformation from confrontational into negotiation strategies transformation from "superman" (authoritarian) into "superteam" culture

transformation from slavery to manumission

transformation from monopoly into ummah-basedeconomic empowerment poor. It is named zakah as it is filled in order to earn blessings for cleansing the soul and nourishing it with all manners of goodness. 


\begin{tabular}{|c|c|c|c|}
\hline & $\begin{array}{l}\text { al-Baqarah/The Heifer } \\
\text { [2]: } 195,262 \text { and } 267\end{array}$ & $\begin{array}{l}\text { Infaq is spending some assets } \\
\text { for an interest ordered by } \\
\text { Islamic teaching. }\end{array}$ & \\
\hline & Q.S. al-Taubah/The & Shadaqah is one of righteous & \\
\hline & Repentance/Immunity: & deeds. Islam invites Muslims & \\
\hline & 60 & $\begin{array}{l}\text { to conduct charity and enjoins } \\
\text { this deed as a form of } \\
\text { compassion toward the } \\
\text { underprivileged and as a form } \\
\text { of help for the poor }\end{array}$ & \\
\hline & $\begin{array}{l}\text { al-Hajj/the Pilgrimage } \\
\text { [22]: } 36)\end{array}$ & $\begin{array}{l}\text { Qurban is a sacrificial animal } \\
\text { slaughtered on Eid al-Adha }\end{array}$ & \\
\hline & & $\begin{array}{l}\text { (e.g., camel, cow, goat), in } \\
\text { which slaughtering is intended } \\
\text { to get Muslims closer to Allah }\end{array}$ & \\
\hline \multirow[t]{12}{*}{8} & Q.S. al-An'ām/The & Tadharru' or humble & transformation from intellectual \\
\hline & Cattle [6]: 42 & $\begin{array}{l}\text { character and awarness of } \\
\text { God's power }\end{array}$ & arrogance into intellectual humility. \\
\hline & $\begin{array}{l}\text { al-Baqarah/The Heifer } \\
\text { [2]: } 139 \text {, }\end{array}$ & $\begin{array}{l}\text { Mukhlish or those who purify } \\
\text { their obedience }\end{array}$ & \\
\hline & Q.S. Ali Imrān/The & Mutawakkilinnor or those who & \\
\hline & Family of Imrān [3]: & surrender to God after making & \\
\hline & al-Māidah [5]: 42 & Muqsițin or those who enforce & \\
\hline & & 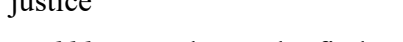 & \\
\hline & al-Hajj/the Pilgrimage & Mukhbitin or those who find & \\
\hline & al-Baqarah/The Heifer & Muttaqin or those who fear & \\
\hline & {$[2]: 2$} & violating Allah's orders & \\
\hline & al-Baqarah/The Heifer & Muflihün or those who take & \\
\hline & {$[2]: 5$} & $\begin{array}{l}\text { pleasure in abiding by } \\
\text { religious teachings }\end{array}$ & \\
\hline
\end{tabular}

One of the eight cultural transformations is transformation from patriarchy to gender equity. Like as the transformation from qabilah into ummah social system, the Prophet also brought a transformation of patriarchy into gender equity. In the early history of Islam, women had the rights to study, fight, and receive inheritances like men. Widowed women were even inheritable to siblings of their late husbands.

The Quran provides many verses related to this patriarchy-to-gender-equity transformation, i.e. equal chance for men and women to support one another and to attain achievements. The surah al-Nisā': 34 is frequently used to justify the common belief that men are superior over women in terms of intellectuality, and, thus, only men are eligible for having positions of leadership. In fact, this verse elucidates on the cooperative and complementary interaction between men and women.

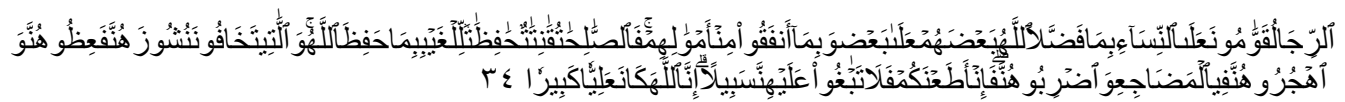

According to Febriani, this verse illustrates a highly harmonious husband-wife relational pattern because Allah designates excellences to each of them and makes them leaders in their respective roles. It is based on phrase qawwāmūn 'alā al-nisā' in the sense that "men are 
guarantors and protectors of the affairs of women,'[6] for in Lisān al-'Arab, the word qawwām means protector. Muhammad 'Abduh [7], Sayyid Qutub [8], Wahbah Zuhailī [9] and Muhammad Quraish Shihab shared their view that term qawwām means to protect, to maintain, and to direct [10].

Musdah Mulia argued that based on this definition, men are expected to provide protection and maintenance for women for having material advantages, for example, in their capacity to provide sustenance. She emphasized that men's superiority referred to in this ayah is limited to material context [11].

Supporting Mulia's argument, Febriani refers to opinions of Amina Wadud [12], Yunahar Ilyas [13], Nur Jannah Ismail [14], and Zaitunah Subhan [14] to argue that men are eligible to be house-leader for two reasons. First, men are blessed with some advantages over women. Second, men are obliged to provide needs for their families. Since Quran does not illustrates aspects in which men are more capable than women, it still keeps various interpretation, starting from advantages in physical and intellectual aspects in terms of religion.

Al-Marāghā and Ibn 'Ādil al-Hanbalī, surprisingly, provides opinions similar to the scholars' ones above. They argue that men's superiority over women is attributable to their responsibilities in fostering and maintaining their households and in providing for their wives and offspring, while these responsibilities are not shared with women. Men are entitled to have more inheritances than women's ones due to men's responsibility to provide financial support to his wife and children [15]. They figure out that men are superior over women only in provisions and inheritances (men's two-thirds as compared to women's one-third) rather than in intellectuality.

Contrary to the arguments above, however, Ṭabātabā' $\overline{1}$ ' interpreted that men's superiority over women is based on their intellectuality, which allows them a greater degree of endurance and perseverance in terms of challenges and hardships. He maintained that women are more emotional in nature, and their lives are built upon gentleness and delicacy [16].

Hamka also stated that men's superiority lies in their energy and intellectuality [17]. Alșabūn̄ added that men are leading in intellectual aspects, while women are in physical aspects. However, both men and women have own advantages of each other, in which ears are no better than eyes and arms are no better than legs [18].

These opinions are in parallel with al-Zamakhshari's exegesis of this ayah in which men are superior over women in terms of intellectuality, firmness, consistency, decision-making. It is based on historical fact that prophets and prominent scholars are men, leader, mujtahid, eligible to make adhan (call to prayer), to deliver Friday sermons (be khatib), and to be marriage guardians, entitled to have talak (divorce) and rujuk (reconciliation), polygamy, among other things [19]. Fakhr al-Rāzī [20] and al-Biqā’'̄ [21] also shared this opinion.

Likewise, al-Qurțubī asserted that men are leading in reasoning, managerial skills, mentality, and instinct, which, according to him, are missing in women [22].

In the period of Prophet, women possessed intellectual and emotional prowess any woman would be proud of. Barbara Freyer Stowasser exemplified the Prophet's wives who have praiseworthy characters. It was narrated that his wives were unshaken in their worship, generous, lived for the pleasure of their husband, educated and raised their children on their own for their husband to perform jihad unworried, had control over themselves, maintained their dignity and pride, defended Islam valiantly against the disbelievers ( $k a \bar{a}$ ir $)$, had considerable comprehension about Islamic law, and had wisdom in religious affairs. [23] They do not lag in intellectual and emotional aspects behind men as was believed by al-Marāghī as well as a couple of other mufassir. 
Meanwhile, Sayyid Qutub has projected a moderate opinion. For him, Allah will never be fallacious in creation. It means that Allah has given special blessings for men and women in order to support his/her marriage and social life. The physical, intellectual, and character excellences of men and women are used for the performance of their functions in their lives, with neither of them being more special than the other [8].

This ayah concerns a specific affair, i.e. an issue of leadership in married life, as opposed to public interests, and only applicable on specific conditions, which is depending on the situation after, before, and during marriage [24]. It means that a man is fit to be a guide and protector in a family only if he has the capacity to provide needs for his wife and children.

There is also a Prophetic hadith admonishing human beings, males and females alike, toward that which is good and against that which is forbidden by Islamic law. He said,

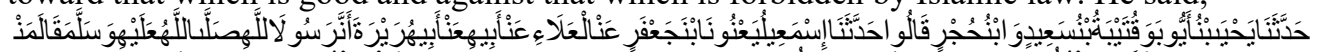

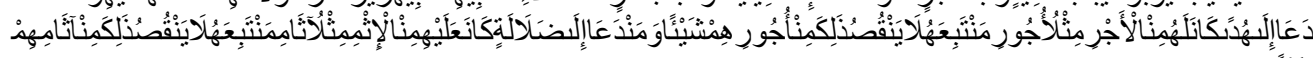

As informed in the ayah and the hadith above, Allah and His Messenger postulated that both men and women consistently in observing amar ma'rüf nahī munkar and preserving a unity of the Muslim ummah will have rewards bestowed upon them proportionate to what they do, without any reduction in the slightest, even for deeds the size of an atom as smallest known constituent unit as of today [25].

\section{Conclusion}

This study concluded that the concept of Prophet's and his Companion's spiritual hijrah is manifested in formats that continuously evolve with the dynamics of recent needs and demands. This transformation is heading to better civilization and justice for all.

The eight forms of cultural transformation brought by the Prophet illustrates that hijrah in the Quran aims not only to create a more civilized culture but also to empower and guarantee all individuals'rights, regardless of tribes, religions, genders, social statuses, among other things.

\section{References}

[1] A. S. Jazuli, Hijrah dalam Pandangan al-Quran. Jakarta: Gema Insani Pers, 2006.

[2] I. Taimiyyah, Majmu' al-Fatāwā. Beirut: Dar al-Fik, 2006.

[3] M. S. Al-Qațani, al-Wala wa al-Bara. Riyadh: Dar al-Thayyibah.

[4] A. al-Hayy Al-Farmawī, al-Bidāyah fì al-Tafsīr al-Maudū' $\bar{\imath}:$ Dirāsah Manhajiyah Maudū'iyyah. Mesir: Maktabah al-Jumhūriyyah.

[5] T. A. Karim, Pemberdayaan Masyarakat dalam Perspektif al-Quran dan Implementasinya di dalam masyarakat Indonesia. Jakarta: Young Progressive Moslem, 2016.

[6] I. Manẓūr, A. Al-Fadhl, J. al-D. Muḥammad, I. M. Al-Afriq̄ī, and Al-Miṣrī, Lisān al'Arab. Beirūt: Dār șādir, 2000.

[7] M. R. Ridhā, Tafsìr al-Manār. Beirūt: Dār al-Kutub al-'Ilmiyya, 1999.

[8] S. Quțub, F̄̄ Zilāl al-Qur'ān. Qāhirah: Dār al-Shurūq, 1998.

[9] W. Zuhailī, al-Tafsīr al-Munīr fì al-'Aqīdah wa al-Sharī'ah wa al-Manhaj. Damshiq: 
Dār al-Fikr, 1998.

[10] M. Q. Shihab, Tafsir al-Mishbah Pesan Kesan dan Keserasian al-Quran. Jakarta: Lentera Hat, 2005.

[11] S. M. Mulia, Muslimah Reformis, Perempuan Pembaharu Keagamaan. Bandung: Mizan, 2005.

[12] A. W. Muhsin, Quran and Woman. Kuala Lumpur: Fajar Bakti, 1992.

[13] I. Yunahar, "Kepemimpinan dalam Keluarga: Pendekatan Tafsir," J. Kaji. Islam alInsan, vol. 3, no. 2, 2006.

[14] I. Nur Jannah, Perempuan dalam Pasungan Bias Laki-Laki dalam Penafsiran. Yogyakarta: LKiS, 2003.

[15] A. M. Al-Marāghī, Tafsīr al-Marāghī. Beirūt: Dār al-Kutub 'Ilmiyyah, 1998.

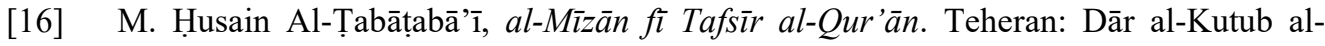
Islāmiyyah.

[17] Hamka, Tafsir al-Azhar. Jakarta: Pustaka Panji Mas, 1983.

[18] 'Alī Ibn al-Jamīl Al-ṣabūnī, șafwah al-Tafāsīr. Madīnah Naṣr: Dār al-ṣabūn̄̄, 1998.

[19] M. I. 'Umar Al-Zamakhsharī, al-Kashshāf "an Haqā"'iq Ghawāmid al-Tanzīl wa "Uyūn al-Aqāwīl fì Wujūh al-Ta”"wìl. Beirūt: Dār al-Kutub al-'Ilmiyyah, 1995.

[20] M. Al-Dīn and A.-R. Fakhr., Tafsīr al-Kabīr wa Mafātih̆ al-Ghaib. Beirūt: Dār al-Fikr, 1995.

[21] B. Al-Biqā̄'̄̄, A.-D. Abī, and al-Hasan I. I. 'Amr., Naẓm al-Durar fì Tanāsub al-Āyāt wa al-Suwar. Beirut: Dār al-Kutub al-'Ilmiyyah, 1995.

[22] A. M. I. A. al-A. Al-Qurțubī, Al-Jāmi“ "li Aḥkām al-Qur”ān. Beirūt: Dār al-Kutub al'Ilmiyyah, 1996.

[23] B. F. Stowasser, Women in The Qur'an, Tradition and Interpretation. New York: Oxford University Press, 1994.

[24] M. Q. Shihab, Perempuan Dari Cinta sampai Seks, Dari Nikah Mut'ah sampai Nikah Sunnah, dari Bias Lama sampai Bias Baru. Jakarta: Lentera Hat, 2006.

[25] N. A. Febriani, Ekologi Berwawasan Gender dalam Perspektif al-Quran. Bandung: Mizan, 2014. 